\title{
Quinine induced blindness
}

Symptoms of cinchonism are well described and consist of headaches, tinnitus, nausea, abdominal pain, and hypotension. Acute intoxication has been associated with blindness, arrhythmias, acute renal failure, and death. Symptoms are likely in any single dose greater than $4 \mathrm{~g}$ and death has been reported with as little as $8 \mathrm{~g} .{ }^{1}$ Quinine is almost completely absorbed from the gut and peak plasma concentrations are reached at about 1 to 3 hours. ${ }^{2}$ It is $70 \%$ protein bound and metabolism occurs in the liver. ${ }^{23}$

In a study of 48 cases, the mean time from ingestion to onset of minor symptoms was 3.5 hours, blindness developed somewhat later, after a mean of 9 hours. Visual loss occurred in every patient with a plasma quinine concentration above $10 \mathrm{mg} / 1 .{ }^{4}$ A level above $15 \mathrm{mg} / \mathrm{l}$ is associated with increasing risk of permanent ocular damage. ${ }^{5}$

The mechanism by which quinine causes ocular toxicity has yet to be defined and is reflected by a lack of effective treatment. The early observation of arteriolar narrowing and disc pallor followed later by macular oedema led to the suggestion that arterial vasoconstriction may cause retinal ischaemia. Other workers have observed this as a late phenomenon occurring after the onset of blindness ${ }^{6}$ and favour direct toxicity to the neuroretina. ${ }^{78}$ Canning et al argue for a toxic mechanism involving interference with cholinergic neurotransmission causing the acute visual loss, with long term visual disturbance either the result of irreversible acute retinal toxicity or secondary to retinal vascular insufficiency. ${ }^{9}$

The natural course of the condition is for vision to improve somewhat over subsequent hours and days leaving a residual constricted field. Therapies have been largely directed towards reducing quinine absorption, enhancing its elimination, and reversing retinal vasoconstriction. It has been shown that continued administration of activated charcoal significantly reduces the plasma half life of quinine. ${ }^{1011}$ Other techniques to enhance elimination including forced acid diuresis, charcoal column haemoperfusion, haemodialysis, and exchange transfusion have been unsuccessful. ${ }^{5}$ Historically, various methods have been used to attempt reversal of retinal vasoconstriction including intravenous sodium nitrite, carbon dioxide inhalation, retrobulbar vasodilators, and anterior chamber paracentesis to reduce intraocular pressure. ${ }^{9}$ Stellate ganglion block (SGB), in an attempt to reduce retinal arteriolar spasm in quinine induced blindness was first advocated in $1946 .{ }^{12}$ SGB is not without risk; the potential for pneumothorax, vascular injury, and inadvertent block to phrenic and recurrent laryngeal nerves is clearly more worrying if bilateral block is undertaken. There is also the possibility of inadvertent subarachnoid or intravascular injection. It has been reported that in a series of six patients where unilateral blocks had been performed, no difference in acuity or visual fields was demonstrable between the treated and untreated eyes. ${ }^{13}$ However, Boscoe et al suggest that success may depend upon early treatment, before the development of visual signs. ${ }^{14}$ The case they described had a high plasma level and yet made a full recovery.

The National Poisons Unit recommends (March 1997) intravenous nitrates as treatment for ocular toxicity when arterial vasoconstriction can be visualised on funduscopy. There were two cases in 1992 where intravenous nitrates were administered and vision was observed to recover. ${ }^{15}$ There is however no direct evidence to show that the intervention had any bearing on the eventual outcome. Nitrates are predominantly venodilators and it may be more appropriate to target therapy towards reversing the observed arteriolar constriction. Nimodipine has been shown to improve outcome in the context of subarachnoid haemorrhage where consequent arterial spasm causes ischaemia. ${ }^{16}$ There is a theoretical risk with vascular dilating therapy that a 'steal' phenomenon may arise resulting in even less perfusion of the ischaemic region. Any such treatment must be titrated against blood pressure and fluids given accordingly.

In summary, advances in the management of quinine overdosage will only be made if more is understood about the mechanism of toxicity and treatments evaluated within the context of controlled trials. Gastric lavage (if under 2 hours) and activated charcoal administered regularly are of proved benefit. Vascular dilatation therapy is unproved, arterial dilators may be a more logical choice but hypotension must be avoided. SGB is not entirely discredited, it may have a place if administered early enough. Patients often present when irreversible ocular damage has already occurred. We suggest that therapies aimed at preventing ocular damage be administered to all patients with a significant history of quinine ingestion before symptoms appear.

A P HALL

University Department of Anaesthesia,

Leicester Royal Infirmary, Leicester

S C WILLIAMS

Department of Radiology, Bristol Royal Infirmary, Bristol

K N RAJKUMAR

N R GALLOWAY

Department of Ophthalmology, Queen's Medical Centre, Nottingham

1 Moffat AC. Clarke's isolation and identification of drugs in pharmaceuticals, body fluids and post-mortem material. 2nd ed. London: Pharmaceutical Press, 1986:954-5.

2 Vale JA, Meredith TJ. Poisoning: diagnosis and treatment. London: Update Books, 1981:121.

3 Ellenhorn MJ, Barceloux DG. Medical toxicology: diagnosis and treatment of human poisoning. New York: Elsevier, 1988:390-5.

4 Dyson EH, Proudfoot AT, Prescott LF, Heyworth R. Death and blindness due to overdose of quinine. BMF 1985; 291:31-3.

5 Bateman DN, Blain PG, Woodhouse KW, Rawlins MD, Dyson H, Heyworth R, et al. Pharmacokinetics and clinical toxicology of quinine overdosage: lack of efficacy of techniques intended to enhance elimination. $Q \mathcal{F}$ Med 1985;214:125-31.

6 Bacon P, Spalton DJ, Smith SE. Blindness from quinine toxicity. $\mathrm{Br} \mathcal{F} \mathrm{Oph}$ thalmol 1988;72:219-24.

7 Francois J, De Rouck A, Cambie E. Retinal and optic evaluation in quinine poisoning. Ann Ophthalmol 1972;4:177-85.

8 Zahn JR, Brinton GF, Norton E. Ocular quinine toxicity followed by electroretinogram, electro-oculogram and pattern visually evoked potential. Am f Optom Physiol Optics 1981;58:492-8.

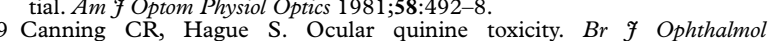
1988;72:23-6.

10 Prescott LF, Hamilton AR, Heyworth R. Treatment of quinine overdose with repeated oral charcoal. Br f Clin Pharmacol 1989;27:95-7.

11 Lockey D, Bateman DN. Effect of oral activated charcoal on quinine elimination. Br f Clin Pharmacol 1989;27:92-4.

12 Redslob E, Warter J, Isch F. Intoxication par la quinine: traitement de la surdite et de l'amaurose consecutive par des infiltrations stellaires. Annals d'Oculistique 1946;179:218-20.

13 Bateman DN, Loydon CR, Ryan DW, Dyson EH. Stellate ganglion blockade and quinine overdose. Anaesthesia 1984;39:71.

14 Boscoe MJ, Calver DM, Keyte C, Ayres JG. Quinine overdose: prevention of visual damage by stellate ganglion block. Anaesthesia 1983;38:669-71 15 Moore D, Marshall J, Henry JA. Research into quinine ocular toxicity. Br $\mathcal{F}$

16 Pickard JD, Murray GD, Illingworth R, Shaw MDM, Teasdale GM, Foy $\mathrm{PM}$, et al. Effect of oral nimodipine on cerebral infarction and outcome after subarachnoid haemorrhage: British aneurysm nimodipine trial. BMF 1989;298:636-42. 